\title{
Article
}

\section{Primary Energy Use and Environmental Effects of Electric Vehicles}

\author{
Efstathios E. Michaelides
}

check for

updates

Citation: Michaelides, E.E. Primary Energy Use and Environmental Effects of Electric Vehicles. World Electr. Veh. J. 2021, 12, 138. https:// doi.org/10.3390/wevj12030138

Academic Editor: Joeri Van Mierlo

Received: 22 July 2021

Accepted: 20 August 2021

Published: 30 August 2021

Publisher's Note: MDPI stays neutral with regard to jurisdictional claims in published maps and institutional affiliations.

Copyright: (C) 2021 by the author. Licensee MDPI, Basel, Switzerland. This article is an open access article distributed under the terms and conditions of the Creative Commons Attribution (CC BY) license (https:// creativecommons.org/licenses/by/ $4.0 /)$.
Department of Engineering, TCU, Fort Worth, TX 76132, USA; E.Michaelides@tcu.edu

Abstract: The global market of electric vehicles has become one of the prime growth industries of the 21st century fueled by marketing efforts, which frequently assert that electric vehicles are "very efficient" and "produce no pollution." This article uses thermodynamic analysis to determine the primary energy needs for the propulsion of electric vehicles and applies the energy/exergy trade-offs between hydrocarbons and electricity propulsion of road vehicles. The well-to-wheels efficiency of electric vehicles is comparable to that of vehicles with internal combustion engines. Heat transfer to or from the cabin of the vehicle is calculated to determine the additional energy for heating and air-conditioning needs, which must be supplied by the battery, and the reduction of the range of the vehicle. The article also determines the advantages of using fleets of electric vehicles to offset the problems of the "duck curve" that are caused by the higher utilization of wind and solar energy sources. The effects of the substitution of internal combustion road vehicles with electric vehicles on carbon dioxide emission avoidance are also examined for several national electricity grids. It is determined that grids, which use a high fraction of coal as their primary energy source, will actually increase the carbon dioxide emissions; while grids that use a high fraction of renewables and nuclear energy will significantly decrease their carbon dioxide emissions. Globally, the carbon dioxide emissions will decrease by approximately $16 \%$ with the introduction of electric vehicles.

Keywords: electric vehicles; electric cars; $\mathrm{CO}_{2}$ emissions; renewable energy; grid stability; transportation efficiency; well-to-wheels efficiency; $\mathrm{CO}_{2}$ avoidance

\section{Introduction}

The first demonstration of a self-powered road vehicle was an electric vehicle (EV): in 1839 Sir William Grove invented and drove a small tractor that was powered by the electricity generated by a fuel cell. The internal combustion (IC) engine, which is a product of the late 19th century, overtook the electric motor as the power source of vehicles and ushered the modern era of the automobile. A contributing factor to the momentous development and market penetration of IC-powered vehicles (ICPVs) is the very large energy storage in relatively small and light tanks, which can be readily tapped to provide a long driving range to the ICPVs: a 60 L gasoline tank, weights $44.2 \mathrm{~kg}$; stores $2052 \mathrm{MJ}$ of chemical energy; and enables a mid-size car to have a range close to $700 \mathrm{~km}$. Electric batteries with capacities of the same order of magnitude were not developed until the early 21st century. For this reason, only vehicles that operate with centrally generated electricity and are connected to the electric grid (intercity trains, subways, trams, etc.) have been in widespread use at the beginning of the 21st century.

Environmental concerns in the 21st century with the rapidly increasing $\mathrm{CO}_{2}$ global emissions; the emissions of other combustion pollutants in urban areas; and the vastly improved battery technology have introduced the new era of electric, battery-powered vehicles. The relatively low price of electricity in most countries, governmental subsidies and tax incentives promote the substitution of ICPVs in favor of the new EVs [1]. Marketing efforts by their manufacturers have also accelerated sales and the wider adoption of EVs. In the marketing efforts, EVs are portrayed as vehicles with very high energy efficiency that would significantly restrain the global consumption and dependence on energy; would 
alleviate the emissions of the greenhouse gases (GHGs) in the transportation sector; and would pave the way (or the highway) to sustainable development.

A great deal of the information on EVs appears in marketing and commercial publications that praise the energy and environmental advantages of EVs. Very few scientific and engineering studies have been published that document these marketing claims. Among the few scientific assessments of EVs, a recent study presented a methodology to estimate the energy use of EVs, based on data from an on-board portable laboratory [2]. This methodology has the potential to establish needed benchmarks for the performance of EVs that are free of untested commercial hyperbolae. A more recent study [3] used the concept of exergy and the thermodynamic methodology to calculate the minimum work needed for the propulsion of road vehicles and derived several useful conclusions on the merits of EVs. Another study [4] examined in detail the pollution reduction benefits of EVs in urban settings and the reduction or replacement of urban pollution with the source-point pollution at the electricity generation power plants. The study also examined several national policies to encourage the citizenry to use EVs for commuting in urban areas. Several other recent studies have analyzed optimization techniques and the effects of EVs on the supply of electricity. Examples are the analysis of charging EVs using renewable energy sources [5], and the effect of fleets of EVS on electric microgrids, also using renewable energy sources [6]. It appears that most of the papers in the literature pertain to the electrical parts of the EVs, such as batteries-including optimized methods for charging and discharging $[7,8]$ — and motors, while fewer studies are related to the overall energy usage and the thermodynamic aspects of the EVs.

This paper uses energy balances, the methodology of thermodynamics, national and global data on electricity generation and $\mathrm{CO}_{2}$ emissions, to determine the primary energy consumption and the associated environmental effects of EVs. The main research question that motivates this study is the clarification or debunking of several concepts related to the energy usage, thermodynamic efficiency, and environmental effects of EVs. Among the contributions (novelties) of this study is the delineation the energy transformations from primary energy sources to electricity, which drives the electric motors of EVs and the calculation of realistic values for the primary energy usage of EVs as well as their overall thermodynamic efficiency. Another contribution is the determination of the effect of heat transfer from the EV cabin on the driving range of electric vehicles. Based on the well-to-wheel efficiencies and the national/regional mixes of electricity generation fuels, the environmental impact of ICPVs substitution with EVs is determined, specifically the avoidance of $\mathrm{CO}_{2}$ emissions. Other contributions of this paper are the requirements for the charging of EVs by solar irradiance in several cities and potential electric grid problems associated with the charging of a fleet of EVs.

\section{Well-to-Wheels Efficiency}

One must consider that EVs use electricity, a tertiary form of energy, which is generated by the conversion of other energy sources [9-11]. Figure 1 shows these energy conversion systems that commence with a primary energy source (the fuel) and finish at the car motor. The "Fuel" in this case is a generic name that applies to a primary energy source; e.g., solar, natural gas, coal, nuclear, etc. This primary energy source is converted to electricity in the power plant; the electricity is transmitted to the battery of the EV; the electric energy is converted to the chemical energy of the battery during charging; and finally, the chemical energy of the battery is converted back to electricity during discharge and runs the motor. 


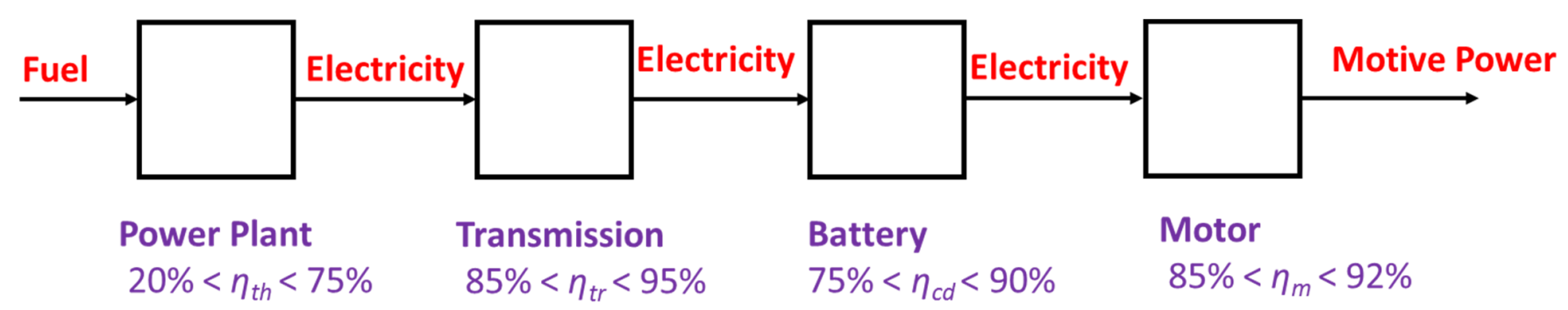

Figure 1. Energy transformation from a primary energy source to the EV motor.

Each one of the energy conversion processes shown in Figure 1 entails energy dissipation, which is quantified by an efficiency. The figure shows the typical range of the average efficiencies for the several processes involved in the conversion of a primary energy source to motive power in the EV. Therefore, for the chain of conversions of the primary energy sources (the only energy sources that are naturally available) to the motive power of the EVs one must take into account the energy losses in the entire range of processes, and this is best quantified by the well-to-wheels (WTW) efficiency $[9,11,12]$ :

$$
\eta_{w t w}=\eta_{e l} \eta_{t r} \eta_{b a t} \eta_{d t}
$$

where $\eta_{e l}$ is the conversion efficiency of the primary energy source to electricity; $\eta_{t r}$ is the transmission efficiency from the power plant to the battery; $\eta_{b a t}$ is the charging efficiency of the EV battery; and $\eta_{d t}$ is the combined efficiency of battery discharging, electric motor and coupling with the wheels of the EV. Table 1 shows typical values of these efficiencies for the conversion of several primary energy sources and the resulting WTW efficiency for EVs.

Table 1. Components of well-to-wheels efficiencies for EVs.

\begin{tabular}{cccccc}
\hline Energy Source & $\eta_{\boldsymbol{c l}}$ & $\eta_{t r}$ & $\eta_{\text {bat }}$ & $\eta_{d t}$ & $\eta_{w t w}$ \\
\hline Biomass & 0.35 & 0.94 & 0.8 & 0.88 & 0.23 \\
Coal & 0.40 & 0.94 & 0.8 & 0.88 & 0.26 \\
Hydroelectric & 0.82 & 0.94 & 0.8 & 0.88 & 0.54 \\
Geothermal & 0.20 & 0.94 & 0.8 & 0.88 & 0.13 \\
Natural Gas & 0.36 & 0.94 & 0.8 & 0.88 & 0.24 \\
Natural Gas Combined Cycle & 0.52 & 0.94 & 0.8 & 0.88 & 0.34 \\
Nuclear & 0.32 & 0.94 & 0.8 & 0.88 & 0.21 \\
Photovoltaics & 0.20 & 0.94 & 0.8 & 0.88 & 0.13 \\
Wind & 0.28 & 0.94 & 0.8 & 0.88 & 0.19 \\
\hline
\end{tabular}

It is apparent in Table 1 that the WTW efficiency of EVs is not very high, except when the electricity is produced by hydroelectric power plants [13]. For the other electricity generation types, the WTW efficiency of EVs is in the range 13-34\%. Tidal, wave, and OTEC energy generation is not included in Table 1 because all three combined generate less than $0.01 \%$ of the electricity produced globally, and they are not expected to generate much more in the future.

For vehicles that use hydrocarbon fuels IC engines the WTW efficiencies include the processes of petroleum exploration, extraction, transportation, and refinement, as well as the thermal efficiency of the IC engine and the transmission efficiency. The pre-combustion processes are typically lumped together in the well-to-tank efficiency, $\eta_{w t t}$, and the remaining processes in the tank-to-wheels efficiency, $\eta_{t t w}$. Hence, for IC vehicles:

$$
\eta_{w t w}=\eta_{w t t} \eta_{t t w}
$$

Because petroleum is a very dense energy source, the energy associated to the before the tank processes is a small fraction of the available energy. An extensive study of eighteen types of vehicles by the Argonne National Laboratory [12] determined that the well-to-tank 
efficiency for gasoline and diesel IC vehicles to be in the range 77-86\%. With the tank-towheels efficiency of mid-size IC engines in the range 14-35\%, the WTW efficiency of the IC-powered cars is in the range $11-30 \%$, with the lower part of the range corresponding to performance and sports vehicles [14]. These efficiencies are comparable to the range of the WTW efficiencies for the EVs [11]. In general, it may be said that IC-powered vehicles have higher well-to-tank efficiencies and lower tank-to-wheels efficiencies, while EVs have lower well-to-tank efficiencies and significantly higher tank-to-wheels efficiencies.

Hybrid electric vehicles with IC engines and smaller batteries have higher WTW efficiencies that oftentimes approach 50\% [9,15]. One may conclude from the consideration of all the energy conversion processes that the "efficiency" of the EVs is comparable to that of typical IC-engine vehicles and that the conversion of a fleet to EVs will not save a great deal of primary energy.

\section{Renewable Energy Utilization-Energy Storage}

The widespread utilization of renewable energy sources is one of the primary goals for a sustainable future, as it is clearly stated in the United Nations document Our Common Future [16] and the more recent report by the Intergovernmental Panel on Climate Change (IPCC), which recommends that the $\mathrm{CO}_{2}$ emissions from the electricity generation sector should be reduced by $90 \%$ or more from the 2010 levels between the years 2040 and 2070 [17]. In a future global society with a large fleet of EVs, it is possible to equip the vehicles or their garages with solar panels that would charge the batteries. Commuter vehicles in large cities are very much suited to this charging scheme, because they are stationed in garages for most of the daylight hours. Given that the EV charging time is flexible, a recent study concluded that the optimization of EV charging in two demographic groups would result in doubling the renewable energy used during the charging process [18]. A similar study outlines all the benefits of the optimized charging of EVs with flexible charging times [19].

The charging of EVs by renewable energy sources implies that sufficient energy supply, in most cases by PV systems or wind is available to charge the vehicles. For inner city garage charging, one would install PV systems on the roofs of garages that would charge the batteries of the hundreds of vehicles within the garage. A moment's reflection, however, proves that the size and area of EVs and most garages are not sufficient for this task. Table 2 shows the results of computations on the surface area of photovoltaics that might supply with $25 \mathrm{kWh}$ electricity the batteries of EVs when they are garaged for nine hours (8:00 a.m. to 5:00 p.m.) in five metropolitan areas of the USA-New York, Boston, Kansas City, Los Angeles, and Miami. The Table also shows the generated power (in $\mathrm{kW} / \mathrm{m}^{2}$ ) and PV area necessary to charge the batteries of a single EV and of $800 \mathrm{EVs}$ (e.g., in garages) in the five cities. Data for the solar irradiance have been obtained for the summer and the winter months from the NREL's National Solar Radiation Data Base [20]. The PV panels are positioned stationary and facing south at the optimum angle for maximum annual energy production, an angle that is approximately equal to the angle of the city's latitude. The overall average efficiency of these commercial PV panels is 20\% [21] and the battery charging efficiency is $85 \%$. In order to avoid weather-related fluctuations in irradiance, ten-day averages (the first ten days of January and July) were used in the calculations.

It is apparent that the surface area of a single vehicle is insufficient to supply its battery daily with $25 \mathrm{kWh}$ using roof-embedded PV cells. Multilevel garages in large cities, where hundreds or even a few thousand cars are parked, also do not have sufficient roof and side areas to charge the EVs. This implies that, if the EVs are to be charged by renewable energy, the electricity must be generated in solar farms outside the urban areas, where land may be plentiful and cheaper. In this case, the battery charging will be laden with additional transmission losses related to inverters, transformers, and transmission lines. 
Table 2. Area required for increasing the charge of EV batteries by $25 \mathrm{kWh}$ with PV cells.

\begin{tabular}{cccc}
\hline City & $\begin{array}{c}\text { Power Generated, } \\
\text { per } \mathbf{~ m}^{\mathbf{2}} \mathbf{~} \mathbf{~ W W}\end{array}$ & $\begin{array}{c}\text { PV Area for 25 kWh } \\
\text { (One EV), } \mathbf{~ m}^{\mathbf{2}}\end{array}$ & $\begin{array}{c}\text { PV Area for 800 } \\
\text { EVs, } \mathbf{~ m}^{\mathbf{2}}\end{array}$ \\
\hline Boston, winter & 0.52 & 56.6 & 45,249 \\
Boston, summer & 0.92 & 32.0 & 25,575 \\
Kansas City, winter & 0.60 & 49.0 & 39,216 \\
Kansas City, summer & 1.14 & 25.8 & 20,640 \\
Los Angeles, winter & 0.97 & 30.3 & 24,257 \\
Los Angeles, summer & 1.18 & 24.9 & 19,940 \\
Miami, winter & 1.08 & 27.2 & 21,786 \\
Miami, summer & 1.20 & 24.5 & 19,608 \\
New York, winter & 0.60 & 49.0 & 39,216 \\
New York, summer & 0.94 & 31.3 & 25,031 \\
\hline
\end{tabular}

An important benefit from the use of a large fleet of EVs that are idle during the morning hours is the availability of energy storage and the avoidance or partly flattening of the "duck curve" effects [22-24], which is shown in Figure 2 for the demand in the city of San Antonio, Texas. When a large fraction of the annual electricity demand is generated by renewables, there is a demand-supply mismatch when the demand is lower, but the supply is high. For PV installations, this typically occurs during the morning hours during the spring and the summer, when the high irradiance produces a great deal of electric power, but the demand is moderate; e.g., because the temperature is not high for the air-conditioning demand to be significant and absorb all the supply [25].

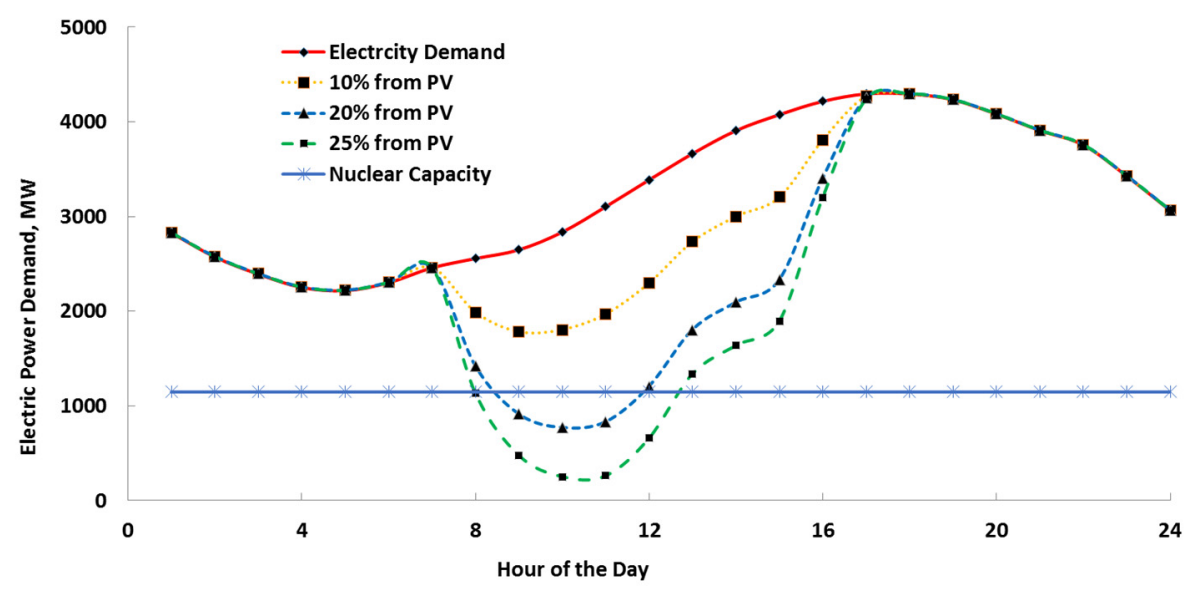

Figure 2. The duck curve generated when the PV-generated electricity reached $10 \%, 20 \%$ and $25 \%$ of the annually generated electricity in the San Antonio, Texas region.

The excess electric energy produced may be stored in the batteries of the EVs to be used later, e.g., after dusk when the solar generated electricity vanishes. This is the so-called vehicle-to-grid (V2G) technology [26-28]. With thousands (perhaps millions) of EV batteries available, a distributed, utility-level energy storage system could be developed that would facilitate the widespread use of renewable energy. However, such a system would suffer from two disadvantages:

1. The round-trip efficiency of energy storage (electric grid-to battery-to electric grid) would be in the range $50-70 \%$, primarily because of the losses in the inverters and transformers [29]. Adverse weather conditions during charging can be detrimental to the charging efficiency [30]. This is a significant disadvantage of all energy storage methods, which implies a large fraction of the electric energy produced is consumed by the thermodynamic irreversibilities of the storage-recovery process, a disadvantage that is shared by all other energy storage systems [11]. 
2. Given that the charging occurs in the morning hours, a large amount of the energy stored must be available for the afternoon and next-morning commute. This "commuting energy" will not be available to the grid.

As a consequence of the above, EV batteries will be able to deliver significantly less energy than their rated capacities. For example, if an EV battery has $55 \mathrm{kWh}$ capacity and the commuting energy is $25 \mathrm{kWh}$, the batter is capable to deliver to the electricity grid only $30 \mathrm{kWh}$. With combined discharge-inverter-transformer efficiencies close to $80 \%$, the consumers in the grid region will receive approximately $24 \mathrm{kWh}$. A recent study for the ERCOT electricity grid in Texas concluded that, even if EV ownership reaches $100 \%$ of the personal vehicles, EVs will only provide a small fraction (3-5\%) of the needed storage for the entire grid. However, and because the round-trip efficiency of battery storage is significantly higher than that of other grid-level storage systems (e.g., hydrogen, PHS and CAES), when priority for discharge is given to the EV batteries, even this very small fraction of battery storage availability significantly reduces the dissipated energy in the storage/recovery process [31].

\section{Charging Time and Grid Stability}

The electric grids of most OECD countries have sufficient capacity to service large fleets of EVs, if the charging is done during nights. Of the energy usage in 2017 globally, 1961 Mtoe were consumed by road vehicles most of them ICPVs [32]. Assuming approximately equivalent well-to-wheel efficiencies, if all these vehicles were to be substituted by EVs, there would be an annual need for an additional 4550 TWh electric energy production globally [33]. This quantity of electricity may be produced by the spare capacity of the electricity generation units during hours of low consumer demand, which usually occurs at nighttime. In the USA, road vehicles consumed 20.1 Quads of hydrocarbon fuels in 2019 [34]. Assuming that all the road vehicles are converted to EVs with equivalent WTW efficiency, the conversion to an all-EV fleet would consume an additional $1080 \mathrm{TWh}$ annually. In 2019 there was 1196 GWh installed generating capacity in the USA, capable of generating a total of approximately 10,500 TWh annually. Since the electric power plants only generated $4236 \mathrm{TWh}$ in 2019 (the generation of electric power units is adjusted to meet the demand of the consumers) the additional 1080 TWh could have been generated by the spare capacity of the electricity grids, e.g., during the nighttime, when the electric power demand is typically low.

Figure 3 depicts the electric power demand during two typical days, one in the summer and one in the winter, for the ERCOT electricity grid of Texas [35]. The rated capacity of all electricity generation units in the region (summer 2021) is $86 \mathrm{GW}$, significantly higher than the peak summer demand [36]. It is apparent in the Figure that the spare generation capacity during the nighttime and early morning hours, would be sufficient to supply with electric energy a large fleet of EVs within the region served by this grid.

In general, the electricity grids of most countries are capable of supporting the charging of EVs, mostly during the nighttime when the demand for electric power by the other sectors of the economy is low. However, substantial problems will arise if EVs are charged during hours of peak demand, and especially if the charging occurred during short periods of time. Let us consider the situation when 1 million EVs within the ERCOT region (there are currently more than 15 million road vehicles within this region) are to be charged by an average of $30 \mathrm{kWh}$ between the hours 5:00 p.m. and 6:00 p.m. on the July day, whose demand is depicted in Figure 3. As shown in the Figure the power demand by the other sectors at 5 p.m. is approximately $67.6 \mathrm{GW}$. Considering a combined transmissiontransformer-inverter efficiency of $85 \%$, the power generating units within the grid would have to supply an additional $37.5 \mathrm{GW}$ during that hour, an additional generating capacity that does not exist within the grid. The sudden spike of demand for electric power would cause grid instabilities and, very likely, blackouts. On the contrary, if the 1 million cars were to be charged over eight hours during the nighttime (e.g., between 11:00 p.m. and 7:00 a.m.) the additional average power needed for these hours is only 4.7 MW. As may 
be seen in Figure 3, the current capacity of the grid ( $86 \mathrm{GW}$ ) is sufficient to supply this additional power without any problems. There is significant research in the area of fastcharging worldwide [37-39], which will hopefully address this supply-demand problem for electricity grids.

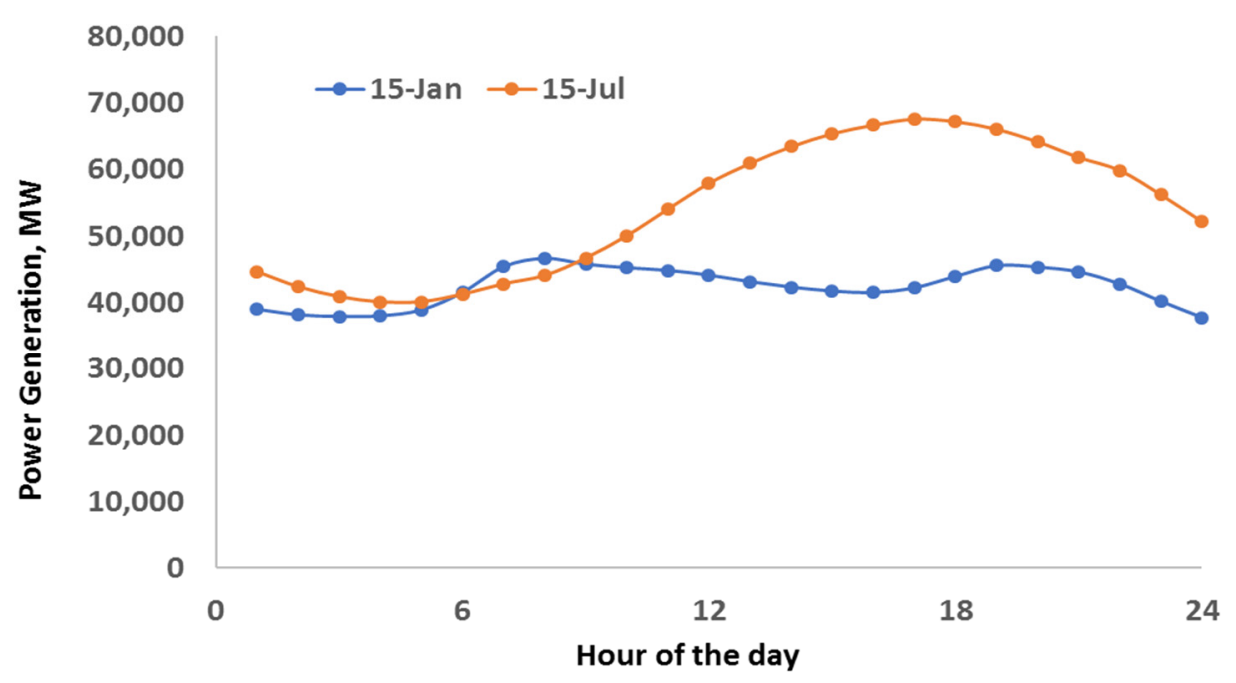

Figure 3. Hourly power generation in ERCOT during two days in 2019.

\section{Distance Range, Heating and Air-Conditioning}

A significant disadvantage of EVs is that the battery is the only energy source and must provide all the energy needs of the vehicle, including heating. While heat is supplied to the IC-engine vehicles by the waste heat in the exhaust gases of the vehicle, the battery must supply all the heating for the cabin of the EV. This is an especially important consideration in cold regions, where the ambient temperature is low in the winter months. Because of this, most EVs use small heat pumps that double as air-conditioning units during the hot season. The rate of heat transferred from any segment of the vehicle may be calculated from the equation [40]:

$$
\dot{Q}_{i}=U A_{i}\left|T_{\text {in }}-T_{0}\right| \text { where } \frac{1}{U}=\frac{1}{h_{\text {in }}}+\frac{\Delta x}{k}+\frac{1}{h_{\text {out }}}
$$

where $U$ is the overall heat transfer coefficient of the segment; $h_{\text {in }}$ is the inside heat transfer coefficient, typically due to natural convection inside the cabin; $h_{\text {out }}$ is the outside heat transfer coefficient, due to forced convection and is a strong function of the vehicle speed; $\Delta x$ is the thickness of the material (glass, metal, composite, etc.) that comprises the vehicle segment; and $k$ is the thermal conductivity of this material. The total rate of heat transferred from the vehicle is obtained by summarizing all the segments of the vehicle cabin which are exposed to the ambient air.

Calculations were performed for the energy requirements of a typical sedan-style $\mathrm{EV}$, when the difference between the interior cabin and ambient is $30^{\circ} \mathrm{C}$ (e.g., when the ambient temperature is $-5^{\circ} \mathrm{C}$ and the cabin is maintained at $25^{\circ} \mathrm{C}$ ) with the heat pump coefficient of performance, $\beta$, as a parameter. The results of the calculations are shown in Figure 4 . The case $\beta=1$ signifies that the EV uses resistance heating and the case $Q=0$ signifies that no heat is needed for the cabin of the EV (this is the power needed for the propulsion of the vehicle at the speed shown). 


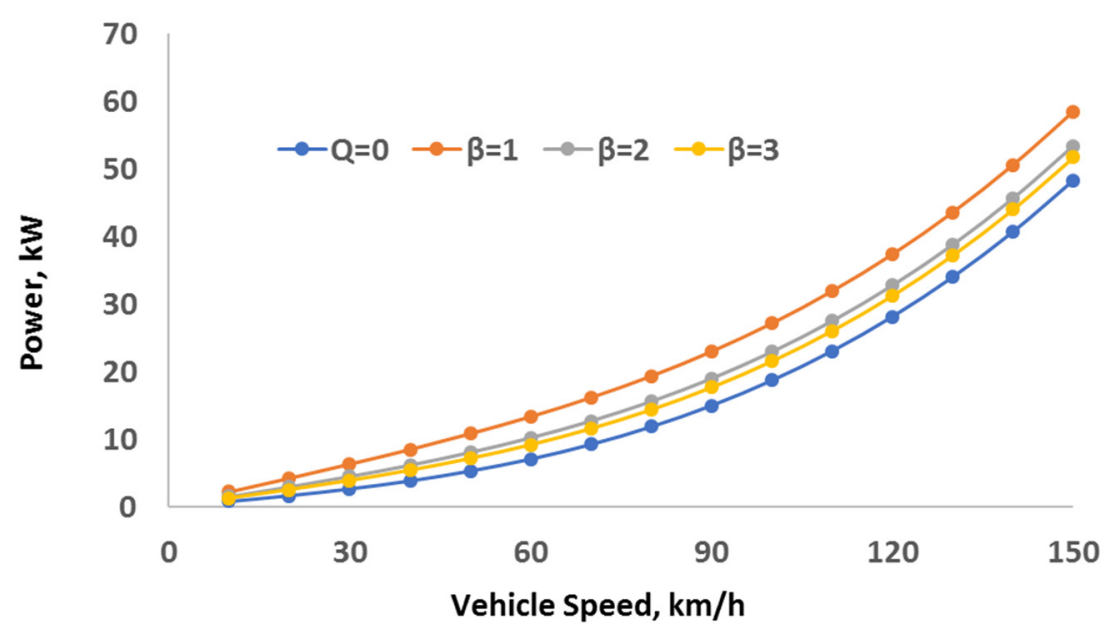

Figure 4. Power needed for EVs as a function of the vehicle speed and the coefficient of performance of the heat pump for $\Delta T=30^{\circ} \mathrm{C}$.

At the cruising speed of $100 \mathrm{~km} / \mathrm{h}$, the power consumption of this vehicle increases by $45 \%$ when it is heated by resistance heating and by $15 \%$ when a heat pump with $\beta=3$ is used. The range of the vehicle (the distance travelled in one charge) would decrease commensurably. It is apparent that the EV power needs increase significantly in colder climates and that a heat pump with a high COP would be beneficial.

\section{6. $\mathrm{CO}_{2}$ Emissions}

One of the principal marketing arguments for the widespread use of EVs is that the vehicles do not emit any greenhouse gases, and particularly $\mathrm{CO}_{2}$, the principal greenhouse gas and principal cause of the global environmental change (GCC). This is correct to a certain extent because the EVs, by themselves, do not emit any pollutants. However, pollutants are emitted at the points where the electric energy in the vehicles has been generated, the power plants. The electric generation units of all countries use fossil fuels for at least part of their electric energy generation. The fraction of fossil fuels used depends on the other native sources for electricity generation and ranges from $1.8 \%$ in Norway (primarily natural gas) to $83.4 \%$ in Estonia (primarily sand tar). The global average of the use of fossil fuels for electricity generation is $62.7 \%$ and includes coal, natural gas, and liquid hydrocarbons [41].

A very good and holistic method to determine the environmental impact of engineering systems is the Life Cycle Assessment (LCA), in which all the pollutants associated with the manufacture, operation and disposal of the systems are determined [42,43]. In the case of EVs, which consume a great deal of energy and are expected to operate for ten years or more, the LCA of $\mathrm{CO}_{2}$ emissions is very close to the emissions of the power units that generate the needed electricity for their operation. Calculations were made for the $\mathrm{CO}_{2}$ emissions avoidance resulting from the substitution of IC-engine vehicles with EVs in several countries that generate electricity by a different mix of primary energy sources. For the calculations of the IC-engine vehicles the $\mathrm{CO}_{2}$ is emitted by the combustion process of the hydrocarbons. For the EVs, the equivalent heat supplied to the fossil fuel generation units is calculated, using data for the fraction of electricity generated by fossil fuels in a particular country. Results of the calculations for several countries are depicted in Table 3. The first column in the Table shows the country; the next four columns show the fraction of electric energy generated by coal, natural gas, petroleum, and by non-carbon emitting primary energy sources $[38,44]$. Biofuels, which absorb their carbon from the $\mathrm{CO}_{2}$ in the atmosphere or from wastes, are considered carbon-neutral energy sources and were included in the non-carbon emitting sources [45]. Since the ICPVs do not utilize the latent heat of the vapor in their emissions, the low-heating value (LHV) data was used for the gasoline. Also, since a fraction of the modern gas turbines that operate with natural 
gas and petroleum increasingly use combined cycles with preheaters, the average of the low- and high- heating values (HHV) was used for the natural gas and petroleum that generate electricity [46]. The fifth column of the Table depicts the $\mathrm{CO}_{2}$ avoidance under the current electricity generation mix, when ICPVs are substituted with EVs. Positive values signify avoidance, while negative values signify $\mathrm{CO}_{2}$ emissions increases. The last two columns in the Table indicate the $\mathrm{CO}_{2}$ avoidance when the WTW efficiencies of EVs are significantly higher than those of the IC-powered vehicles by factors 1.2 and $1.4(20 \%$ and $40 \%$ WTW efficiency improvement). This because it is believed that future efficiency improvements and $\mathrm{CO}_{2}$ avoidance may be achieved if the following trends in the manufacturing of EVs continue:

1. Lower weight.

2. More efficient charging and discharging processes.

3. On the electricity generation side, improvements of the generation efficiencies (this happens primarily with the introduction of combined cycle units).

4. Reduction of the carbon footprint of the electric power generation mix (e.g., by the substitution of coal units with renewables $[38,43,47])$.

Table 3. $\mathrm{CO}_{2}$ emissions avoidance related to the substitution of ICPVs with EVs.

\begin{tabular}{|c|c|c|c|c|c|c|c|}
\hline Country & Coal & Natural Gas & Petroleum & Non-Carbon & $\begin{array}{c}\mathrm{CO}_{2} \\
\text { Avoidance, \% }\end{array}$ & $\begin{array}{l}\mathrm{CO}_{2} \text { Avoidance } 20 \% \\
\text { Efficiency Improv., } \%\end{array}$ & $\begin{array}{l}\mathrm{CO}_{2} \text { Avoidance } 40 \% \\
\text { Efficiency Improv., \% }\end{array}$ \\
\hline Australia & 0.6271 & 0.196 & 0.0204 & 0.1565 & -17.32 & 2.28 & 16.24 \\
\hline Belgium & 0.028 & 0.265 & 0 & 0.707 & 73.63 & 78.04 & 81.17 \\
\hline Brazil & 0.045 & 0.098 & 0.026 & 0.831 & 81.97 & 84.98 & 87.13 \\
\hline Canada & 0.091 & 0.087 & 0.011 & 0.811 & 77.26 & 81.05 & 83.76 \\
\hline Chile & 0.369 & 0.168 & 0.024 & 0.439 & 25.31 & 37.78 & 46.67 \\
\hline Estonia & 0.836 & 0.005 & 0.009 & 0.15 & -33.20 & -10.95 & 4.90 \\
\hline Eur. Union & 0.226 & 0.188 & 0.018 & 0.568 & 46.85 & 55.72 & 62.05 \\
\hline France & 0.026 & 0.072 & 0.013 & 0.889 & 88.53 & 90.45 & 91.81 \\
\hline Germany & 0.372 & 0.131 & 0.008 & 0.489 & 29.63 & 41.38 & 49.76 \\
\hline India & 0.748 & 0.048 & 0.016 & 0.188 & -23.64 & -2.99 & 11.72 \\
\hline Japan & 0.329 & 0.373 & 0.0654 & 0.2326 & 10.15 & 25.16 & 35.85 \\
\hline Mexico & 0.096 & 0.59 & 0.119 & 0.195 & 23.12 & 35.96 & 45.11 \\
\hline Norway & 0.00127 & 0.017 & 0 & 0.98173 & 98.39 & 98.66 & 98.85 \\
\hline P.R. China & 0.682 & 0.027 & 0.034 & 0.257 & -13.44 & 5.50 & 19.00 \\
\hline $\begin{array}{l}\text { Russian } \\
\text { Fed. }\end{array}$ & 0.157 & 0.478 & 0.01 & 0.355 & 34.57 & 45.49 & 53.28 \\
\hline $\begin{array}{l}\text { South } \\
\text { Korea }\end{array}$ & 0.451 & 0.222 & 0.02 & 0.307 & 8.34 & 23.65 & 34.55 \\
\hline UK & 0.0689 & 0.404 & 0.005 & 0.5221 & 55.13 & 62.62 & 67.96 \\
\hline USA & 0.308 & 0.312 & 0.008 & 0.372 & 24.73 & 37.30 & 46.26 \\
\hline $\begin{array}{l}\text { World } \\
\text { Aver. }\end{array}$ & 0.384 & 0.232 & 0.037 & 0.347 & 16.24 & 30.22 & 40.19 \\
\hline
\end{tabular}

It is observed in Table 3 that the substitution of the ICPVs with EVs, on the average, reduces the $\mathrm{CO}_{2}$ emissions by $16.24 \%$. However, this effect is local and depends on the primary sources that generate electricity in each country or electricity grid. In countries such as Norway and Canada that generate a high fraction of their electricity by hydroelectric units, as well as in countries such as France and Japan that use a high fraction of nuclear energy, the $\mathrm{CO}_{2}$ avoidance is very high. On the contrary, in countries such as P.R. China, Australia, and India, which produce a great deal of their electric power from coal, the substitution of IC-engine vehicles with EVs will result in a net increase of $\mathrm{CO}_{2}$ emissions. It is also observed in Table 3 that the $\mathrm{CO}_{2}$ avoidance will improve as the WTW efficiency of EVs improves and as the fraction of renewable energy sources in the electricity generating mix increases. Figure 5 depicts the data of Table 3 as percentages of the fossil fuels used for electricity generation and $\mathrm{CO}_{2}$ avoidance. The current global average is shown as a red square in the graph. The slope of the trendline is -1.4 , signifying that for every $1 \%$ reduction of fossil fuels sources for the generation of electricity there is $1.4 \%$ increase of $\mathrm{CO}_{2}$ avoidance when IC-powered cars are substituted by EVs. It is apparent from the 
study of Table 3 and Figure 5 that parameters such as the fraction of renewable energy sources used for the generation of electric power and the promotion of EVs in a nation or a region can be added to the extensive set of guidelines for ecological and environmental improvement that are included in the TRIZ-based guidelines, which were the subject of a recent study [48].

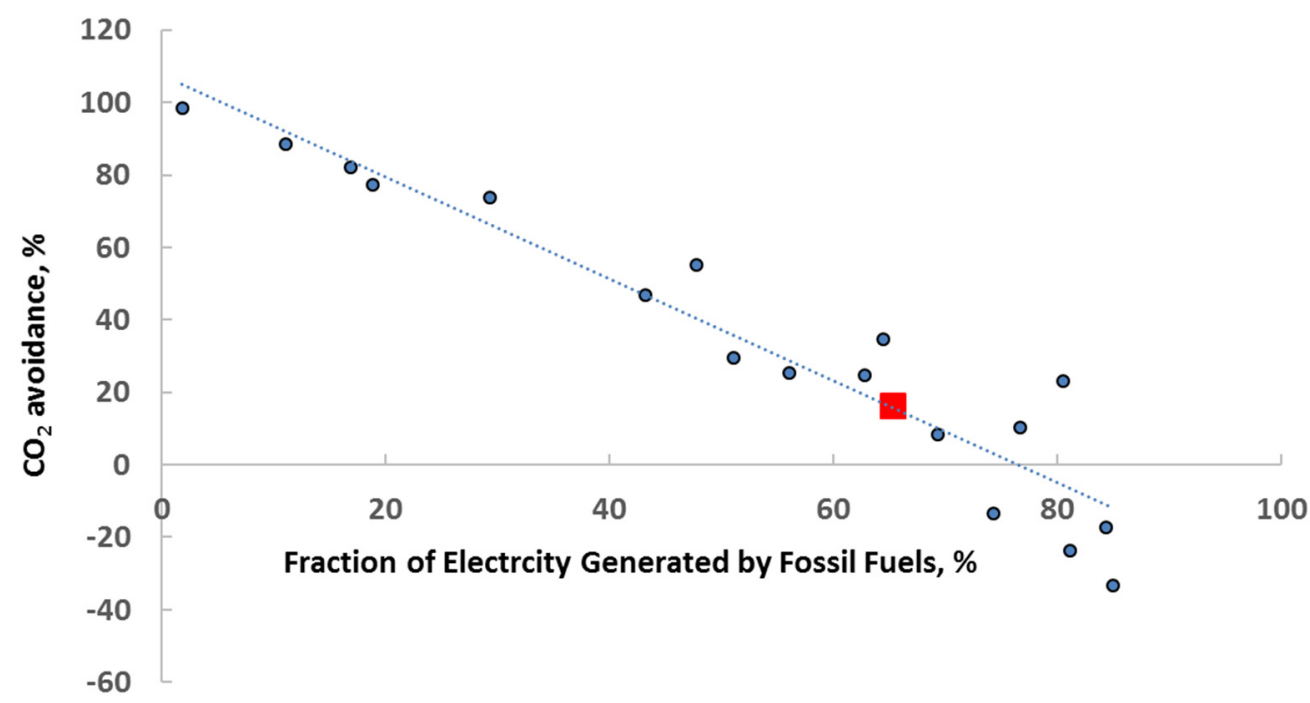

Figure 5. Graphical representation of the $\mathrm{CO}_{2}$ avoidance results.

It must be noted that, although the avoidance of the $\mathrm{CO}_{2}$ emissions is a worthwhile goal, consumers will drift to the energy form that minimizes their overall cost of transportation, not necessarily to minimize their $\mathrm{CO}_{2}$ emissions. A recent study on plug-in hybrid vehicles used optimization objectives for drivers (minimization of the operational costs during vehicle charging and operation) and of governments (reduction of emissions) charging and concluded that the different objectives lead to different charging-discharging outcomes [49]. A subsequent study concluded that the price of electricity in the determines the charging and use of electricity for the hybrid vehicles and that incentives must be offered to their owners in order to ensure optimum environmental results [50].

\section{Conclusions}

This paper critically examines some of the misconceptions promulgated by commercial marketing campaigns for EVs using the methodology of thermodynamics. The WTW efficiency, which connects the final energy use with primary energy sources, indicates that the overall primary energy conversion efficiencies of EVs is comparable to those of ICPVs and (on the average) less than hybrid vehicles. Heat transfer to or from the vehicles-for passenger comfort during extreme weather conditions-requires additional energy, which must be supplied by the battery. This significantly reduces the range of EVs, especially if heating is supplied by electric resistances and not heat pumps. The charging of EV batteries may be accomplished using renewable energy sources, primarily solar energy, which is periodically variable. The PV area required for the charging of EVs in several American metropolitan areas by far exceeds the surface area of the vehicles themselves. Also, for grid stability and the avoidance of excess electric power demand, it is best to slowly charge the EVs during night hours, when electricity demand is lower. Regarding $\mathrm{CO}_{2}$ emissions avoidance, the effect of EVs depends on the methods and technology of electricity generation. A study of the electricity generation in several countries reveals that only in countries where a large fraction of electricity is generated by nuclear and renewables does the substitution of ICPVs with EVs have a significant impact on $\mathrm{CO}_{2}$ avoidance. 
Funding: This research work was partly supported by the W.A. (Tex) Moncrief Chair in Engineering at TCU.

Conflicts of Interest: The author declares no conflict of interest.

\section{References and Notes}

1. Becker, T.A.; Sidhu, I.; Tenderich, B. Electric Vehicles in the United States A New Model with Forecasts to 2030; CET Report; University of California, Berkeley: Berkeley, CA, USA, 2009.

2. Alves, J.; Baptista, P.C.; Gonçalves, G.A.; Duarte, G.O. Indirect methodologies to estimate energy use in vehicles: Application to battery electric vehicles. Energy Convers. Manag. 2016, 124, 116-129. [CrossRef]

3. Michaelides, E.E. Thermodynamics and Energy Usage of Electric Vehicles. Energy Convers. Manag. 2020, 203, 112246. [CrossRef]

4. Van Wee, B.; Maat, K.; De Bont, C. Improving sustainability in urban areas: Discussing the potential for transforming conventional car-based travel into electric mobility. Eur. Plan. Stud. 2021, 20, 95-110. [CrossRef]

5. Bansal, S.; Zong, Y.; You, S.; Mihet-Popa, L.; Xiao, J. Technical and Economic Analysis of One-Stop Charging Stations for Battery and Fuel Cell EV with Renewable Energy Sources. Energies 2020, 13, 2855. [CrossRef]

6. Shi, R.; Zhang, P.; Zhang, J.; Niu, L.; Han, X. Multi-dispatch for Microgrid including Renewable Energy and Electric Vehicles with Robust Optimization Algorithm. Energies 2020, 13, 2813. [CrossRef]

7. Uzair, M.; Abbas, G.; Hosain, S. Characteristics of Battery Management Systems of Electric Vehicles with Consideration of the Active and Passive Cell Balancing Process. World Electr. Veh. J. 2021, 12, 120. [CrossRef]

8. Jing, W.; Yan, Y.; Kim, I.; Sarvi, M. Electric vehicles: A review of network modelling and future research needs. Adv. Mech. Eng. 2016, 8, 1-8. [CrossRef]

9. Dunlap, R.A. A simple and objective carbon footprint analysis for alternative transportation technologies. Energy Environ. Res. 2013, 3, 33-39. [CrossRef]

10. Poullikkas, A. A comparative overview of large-scale battery systems for electricity storage. Renew Sustain. Energy Rev. 2013, 27, 778-788. [CrossRef]

11. Michaelides, E.E. Energy, the Environment, and Sustainability; CRC Press: Boca Raton, FL, USA, 2018.

12. Brinkman, N.; Wang, M.; Weber, T.; Darlington, T. Well-to-Wheels Analysis of Advanced Fuel/Vehicle Systems-A North American Study of Energy Use, Greenhouse Gas Emissions, and Criteria Pollutant Emissions; ANL Report; OSTI: Oak Ridge, TN, USA, 2005.

13. Several countries with excess hydroelectric capacity, such as Norway, aggressively promote the use of EVs.

14. It must be noted that the WTT efficiency for the petroleum products does not include any intangible factors, such as geopolitical events and military actions that are often attributed to the availability of petroleum.

15. Elgowainy, A.; Han, J.; Poch, L.; Wang, M.; Vyas, A.; Mahailik, M.; Rousseau, A. Well-to-Wheels Analysis of Energy Use and Greenhouse Gas Emissions of Plug-In Hybrid Electric Vehicles; ANL Report, ANL/ESD/10/1; OSTI: Oak Ridge, TN, USA, 2010.

16. Our Common Future. Available online: http://www.un-documents.net/our-common-future.pdf (accessed on 15 June 2020).

17. IPCC. 2014: Climate Change 2014: Synthesis Report. Contribution of Working Groups I, II and III to the Fifth Assessment Report of the Intergovernmental Panel on Climate Change Core Writing Team; Pachauri, R.K., Meyer, L.A., Eds.; IPCC: Geneva, Switzerland, 2014.

18. Schuller, A.; Flath, M.C.; Gottwalt, S. Quantifying load flexibility of electric vehicles for renewable energy integration. Appl. Energy 2015, 151, 335-344. [CrossRef]

19. Wu, F.; Sioshansi, R. A two-stage stochastic optimization model for scheduling electric vehicle charging loads to relieve distribution-system constraints. Transp. Res. Part B Methodol. 2017, 102, 55-82. [CrossRef]

20. Wilcox, S.S. National Solar Radiation Database 1991-2010 Update: User's Manual; Technical Report NREL/TP-5500-54824; National Renewable Energy Laboratory: Golden, CO, USA, 2012.

21. Kurtz, S.; Levi, D. Best Research-Cell Efficiencies 2017. Available online: https:/ /www.nrel.gov/pv/assets / images/efficiencychart.png (accessed on 30 June 2020).

22. Freeman, E.; Occello, D.; Barnes, F. Energy Storage for Electrical Systems in the USA. AIMS Energy 2016, 4, 856-875. [CrossRef]

23. California ISO (CAISO). What the Duck Curve Tells Us about Managing a Green Grid. 2016. Available online: https://www. caiso.com/Documents/FlexibleResourcesHelpRenewables_FastFacts.pdf (accessed on 31 May 2021).

24. Denholm, P.; O'Connell, M.; Brinkman, G.; Jorgenson, J. Over-Generation from Solar Energy in California: A Field Guide to The Duck Chart, National Renewable Energy Laboratory; Technical Report NREL/TP-6A20-65023; National Renewable Energy Laboratory: Golden, CO, USA, 2015.

25. DeValeria, M.K.; Michaelides, E.E.; Michaelides, D.N. Energy and Thermal Storage in Clusters of Grid-Independent Buildings. Energy 2019, 190, 116440. [CrossRef]

26. Bartolini, A.; Comodi, G.; Salvi, D.; Østergaard, P.A. Renewables self-consumption potential in districts with high penetration of electric vehicles. Energy 2020, 213, 118653. [CrossRef]

27. Raveendran, V.; Alvarez-Bel, C.; Nair, M.G. Assessing the ancillary service potential of electric vehicles to support renewable energy integration in touristic islands: A case study from Balearic island of Menorca. Renew. Energy 2020, 161, 495-509. [CrossRef]

28. Pearre, N.S.; Swan, L.G. Electric vehicle charging to support renewable energy integration in a capacity constrained electricity grid. Energy Convers. Manag. 2016, 109, 130-139. [CrossRef]

29. Apostolaki-Iosifidou, E.; Codani, P.; Kempton, W. Measurement of power loss during electric vehicle charging and discharging. Energy 2017, 127, 730-742. [CrossRef] 
30. Shirazi, Y.A.; Sachs, D.L. Comments on Measurement of power loss during electric vehicle charging and discharging-Notable findings for V2G economics. Energy 2018, 142, 1139-1141. [CrossRef]

31. Michaelides, E.E.; Nguyen, V.D. Fossil Fuels to Renewables Substitution-The Effect of Electric Vehicles. Renew. Energy. accepted for publication.

32. International Energy Agency. Key World Statistics; IEA: Paris, France, 2018.

33. It must be recognized that this is a maximum amount of needed electric energy because not all the road vehicles will be converted to EVs.

34. US-DOE, Energy Information Agency. 2020. Available online: https://www.eia.gov/totalenergy/data/monthly/index.php\# consumption (accessed on 30 June 2020).

35. ERCOT. Electricity Grid of Texas. Available online: http://www.ercot.com/gridinfo/generation (accessed on 31 January 2021).

36. ERCOT. Fact Sheet. 2021. Available online: http:/ / www.ercot.com/gridinfo (accessed on 20 June 2021).

37. Wolbertus, R.; van den Hoed, R. Fast Charging Systems for Passenger Electric Vehicles. World Electr. Veh. J. 2020, 11, 73. [CrossRef]

38. Mandrile, F.; Cittanti, D.; Mallemaci, V.; Bojoi, R. Electric Vehicle Ultra-Fast Battery Chargers: A Boost for Power System Stability? World Electr. Veh. J. 2021, 12, 16. [CrossRef]

39. ten Have, S.Y.; Gkiotsalitis, K.; Geurs, K.T. Investigating the Future of Ultrafast Charging: A Choice Experiment in the Netherlands. World Electr. Veh. J. 2020, 11, 70. [CrossRef]

40. Incropera, F.; DeWitt, D.P. Fundamentals of Heat and Mass Transfer, 3rd ed.; Willey: New York, NY, USA, 2020.

41. International Energy Agency. Electricity Information-2019; IEA: Paris, France, 2020.

42. Meyer, L.; Tsatsaronis, G.; Buchgeister, J.; Schebek, L. Exergoenvironmental analysis for evaluation of the environmental impact of energy conversion systems. Energy 2015, 34, 75-89. [CrossRef]

43. Michaelides, E.E. Exergy and the Conversion of Energy; Cambridge University Press: Cambridge, UK, 2021.

44. US DOE. International Energy Outlook 2019, Washington DC. 2020. Available online: https://www.eia.gov/international/ overview / world (accessed on 15 June 2020).

45. Ramachandran, S.; Stimming, U. Well to wheel analysis of low carbon alternatives for road traffic. Energy Environ. Sci. 2015, 8, 3313-3324. [CrossRef]

46. Fuels-Higher and Lower Calorific Values. Available online: https://www.engineeringtoolbox.com/fuels-higher-calorificvalues-d_169.html (accessed on 15 June 2020).

47. Leonard, M.D.; Michaelides, E.E.; Michaelides, D.N. Substitution of coal power plants with renewable energy sources-Shift of the power demand and energy storage. Energy Convers. Manag. 2018, 164, 27-35. [CrossRef]

48. Russo, D.; Spreafico, C. TRIZ-based guidelines for eco-improvement. Sustainability 2020, 12, 3412. [CrossRef]

49. Kontou, E.; Yin, Y.; Ge, Y.E. Cost-effective and ecofriendly plug-in hybrid electric vehicle charging management. Transp. Res. Rec. 2017, 2628, 87-98. [CrossRef]

50. Chakraborty, D.; Hardman, S.; Tal, G. Why do some consumers not charge their plug-in hybrid vehicles? Evidence from Californian plug-in hybrid owners. Environ. Res. Lett. 2020, 15, 084031. [CrossRef] 